\title{
SPIRITUAL WORLDLINESS SEBAGAI ANCAMAN BESAR GEREJA SEPANJANG ZAMAN
}

\author{
Mario Tomi Subardjo
}

\begin{abstract}
:
Henri de Lubac describes spiritual worldliness as the worst temptation for the Chruch. De Lubac's thought about spiritual worldliness is frequently cited by Pope Francis.This temptation threatens and brings the Church into destruction. The way to prevent this temptation is to understand the church's identity and mission correctly. If the Church does not maintain the tensions in the way she understands herself, she falls into worldliness. The tendency to understand the Church only in her human or divine dimension will bring the Church into worldliness. This article will help the Church in examining herself, whether she is doing her mission for the greater glory of God or she is doing it for her own glory.
\end{abstract}

\section{Kata-kata kunci:}

Nouvelle Théologie, spiritual worldliness, kodrat, ontologi sakramental, ekstrinsikisme, eklesiologi komunio, Gereja sebagai sakramen, paradoks.

\section{BAHAYA SPIRITUAL WORLDLINESS}

Spiritual worldliness atau keduniawian spiritual, merupakan ancaman besar bagi Gereja. Ancaman ini dirumuskan dan dipopulerkan oleh seorang teolog Perancis bernama Henri de Lubac (1899-1991). Pemikiran de Lubac mengenai keduniawian spiritual ini sering dikutip oleh Paus Fransiskus. Seringnya Paus Fransiskus mengingatkan Gereja akan adanya bahaya keduniawian spiritual merupakan indikasi bahwa Gereja masa kini rentan untuk jatuh dalam godaan ini.

Kardinal Jorge Mario Bergoglio dalam pertemuan umum para kardinal pada tanggal 9 Maret 2013 sebelum sidang konklaf yang akhirnya memilihnya menjadi Paus, mengutip pemikiran de Lubac mengenai spiritual worldliness ini. Pada kesempatan itu Bergoglio mengatakan bahwa Gereja berada dalam situasi bahaya ketika ia tidak keluar dari dirinya sendiri untuk mewartakan Injil. Gereja ada dalam bahaya serius ketika ia berpuas diri dan percaya bahwa ia mempunyai cahaya bagi dirinya sendiri. Pada waktu itu Gereja berhenti menjadi mysterium lunae dan justru memberi jalan bagi "yang jahat", yang disebut oleh de Lubac sebagai spiritual worldliness. Spiritual worldliness ini disebut oleh Bergoglio sebagai kemungkinan terburuk di mana Gereja bisa terperosok ke dalamnya. ${ }^{1}$

Intervensi Kardinal Bergoglio dalam sidang umum menjelang konklaf tanggal 9 Maret 2013 ini berfokus pada tema evangelisasi. Bergoglio menegaskan kembali apa yang pernah dikatakan oleh Paus Paulus VI bahwa alasan utama bagi adanya Gereja adalah kegembiraan yang besar karena mewartakan Injil. Dalam intervensi tersebut Bergoglio mengangkat dua gambaran Gereja: pertama, Gereja yang mewartakan Injil, yang keluar dari dirinya sendiri 
dan kedua, Gereja duniawi yang hidup dalam, dari, dan untuk dirinya sendiri. Gambaran Gereja yang pertama inilah yang harus menerangi segala usaha perubahan dan perbaikan yang perlu diwujudkan demi keselamatan jiwa-jiwa. ${ }^{2}$

Pada tahun 2007, Kardinal Bergoglio pernah diwawancarai dan ditanya mengenai situasi Gereja zaman ini. Ketika seorang pewawancara menanyakan mengenai hal terburuk seperti apa yang mungkin dihadapi Gereja, Bergoglio secara eksplisit meminjam pemikiran de Lubac mengenai spiritual worldliness. Ia mengatakan demikian:

"Hal terburuk yang mungkin terjadi pada Gereja adalah apa yang disebut oleh de Lubac sebagai spiritual worldliness. Inilah bahaya terbesar bagi Gereja, bagi kita yang ada di dalam Gereja. spiritual worldliness ini lebih berbahaya dari pada kusta yang merusak mempelai-Nya. spiritual worldliness menempatkan seseorang di pusat. Inilah yang dilihat Yesus dalam diri orang-orang Farisi." 3

Bergoglio setelah menjadi Paus mengutip kembali pemikiran de Lubac mengenai spiritual worldliness saat memberi sambutan pada pertemuan para duta besar Vatikan tanggal 21 Juni 2013. Ia mengatakan bahwa ada risiko bagi "orang-orangnya Gereja" untuk jatuh pada spiritual worldliness. Ada risiko untuk kalah terhadap godaan roh jahat yang menuntun mereka pada pemenuhan diri sendiri lebih dari pada kemuliaan Allah. Roh ini mengarahkan orang untuk mencari selalu yang enak dan nyaman. ${ }^{4}$

Dalam Anjuran Apostolis Evangelii Gaudium, pokok mengenai spiritual worldliness kembali dikutip. Paus Fransiskus mengatakan bahwa keduniawian ini bisa tersamar dalam olah kesalehan dan bahkan dalam rasa cinta kepada Gereja. Di balik kesalehan dan rasa cinta itu sebenarnya yang dicari bukan kemuliaan Allah tetapi kemuliaan dan keselamatan diri sendiri. Dalam ekshortasi ini Paus Fransiskus menunjukkan bahwa spiritual worldliness mengarah pada dua kutub. Yang pertama mengarah pada gnostisisme di mana iman sepenuhnya dipahami secara subyektif.
Gnostisisme menaruh perhatian pada pengalaman atau ide-ide tertentu yang menerangi dan memuaskan manusia tetapi justru membuat orang terperangkap dalam pikiran-pikiran dan perasaan-perasaan mereka sendiri. Yang kedua spiritual worldliness ini mengarah pada neoPelagianisme promethean yang akhirnya hanya menaruh kepercayaan pada usaha mereka sendiri dan oleh karenanya merasa superior atas orang lain. Orang merasa lebih dari pada orang lain karena sudah menjalankan berbagai macam aturan atau karena tetap setia pada gaya kekatolikan tertentu yang berasal dari masa lalu. Spiritual worldliness ini mengarah pada elitisme narsisistik dan otoriter. Alih-alih mewartakan Injil dan membuka pintu kepada rahmat Allah, orang menghabiskan energi untuk sibuk dan memverifikasi praktek-praktek keagamaannya. Paus Fransiskus mengatakan bahwa pewartaan yang sungguh-sungguh tidak mungkin muncul dari bentuk kristianitas semacam ini. $^{5}$

\section{RUMUSAN MASALAH}

Istilah spiritual worldliness yang sering diacu oleh Paus Fransiskus untuk menunjukkan ancaman terbesar terhadap Gereja berasal dari pemikiran Henri de Lubac. Jika demikian, apa yang menjadi latar belakang atau kecenderungan teologis dan filosofis di balik munculnya rumusan spiritual worldliness oleh de Lubac ini?

Spiritual worldliness merupakan ancaman besar bagi Gereja. Paus Fransiskus berulangkali menekankan bahaya ini. Apa saja indikasi Gereja yang jatuh ke dalam keduniawian? Hal-hal apa saja yang perlu diperhatikan oleh Gereja sebagai ramburambu supaya ia tidak jatuh ke dalam keduniawian ini?

\section{HENRI DE LUBAC DAN NOUVELLE THÉOLOGIE}

Apa yang menjadi kekhasan teologi de Lubac dan didasari oleh keprihatinan apa? Joseph A. Komonchak memberikan gambaran yang bisa dipakai untuk melihat latar belakang kekhasan teologi de Lubac. $^{6}$ Teologi de Lubac, juga teologi Konsili Vati- 
kan II perlu dilihat secara lebih menyeluruh dalam konteks perkembangan kekatolikan 150 tahun sebelumnya. Sejak masamasa itu kekristenan tidak lagi mempunyai monopoli dalam menentukan dinamika kebudayaan Eropa. Komonchak membahasakan bahwa teologi dalam masa tersebut berada dalam pembuangan dari kebudayaan dunia modern. Teologi yang ada dalam pembuangan itu justru berhenti dalam suatu geto intelektual. Artinya, teologi menjadi terpisah dari realitas perkembangan hidup konkret masyarakat. Dalam konteks seperti inilah Komonchak melihat bahwa Nouvelle Théologie merupakan sebuah usaha untuk membawa kembali teologi dari pembuangannya. Dengan kata lain, Komonchak melihat bahwa ada gerakan dikalangan sejumlah teolog yang berhasrat untuk melihat adanya relasi antara Gereja dengan budaya modern.

De Lubac mempunyai perhatian untuk kembali membuat teologi menjadi signifikan dalam budaya modern. Komonchak melihat bahwa pemikiran teologis de Lubac mengenai yang adikodrati sangat erat terkait dengan fenomena ketidakpercayaan dunia modern. Ia mengatakan bahwa jika saat ini secara umum banyak orang menarik diri dari kekristenan, maka hal ini mungkin disebabkan karena kekristenan terlalu sering dicabut dari bagian-bagian kehidupan manusia yang sungguh sangat penting.

Teologi Gereja Katolik akhir abad XIX dan paruh pertama abad XX sangat didominasi oleh warna tunggal teologi neoThomis yang mengusung interpretasi tertentu atas pemikiran Thomas Aquinas. Dari bagian sebelumnya nampak bahwa Gereja punya kecenderungan sangat anti dengan model berteologi yang tidak didasarkan pada manual teologi Thomas Aquinas. Model berteologi yang lain dari pada yang diajarkan Gereja dianggap sebagai teologi yang keliru dan terjangkiti modernisme. Para "teolog modern" ini bermunculan di berbagai tempat, termasuk di Perancis.

Di Perancis muncul sejumlah tokoh intelektual di era tahun 1930-an. Bisa dikatakan bahwa bahwa era ini merupakan salah satu periode emas kehidupan intelektual di Perancis baik di bidang literatur, filsafat, maupun teologi. Dalam bidang filsafat, sebagaimana sudah disinggung pada bagian awal bab ini ada nama-nama seperti Maurice Blondel, Jacques Maritain, Etiene Gilson, Gabriel Marcel, dan Emmanuel Mounier. Di bidang teologi muncul tokoh-tokoh yang lebih muda seperti Teilhard de Chardin, M.D. Chenu, Yves Congar, Henri de Lubac, dan Gaston Fessard. Pemikiran para tokoh ini sangat kontras dengan karya-karya generasi sebelumnya. Karya generasi yang lebih muda ini ditandai dengan gerakan menuju keterlibatan aktif dan kritis dalam masyarakat dan budaya di tengah-tengah krisis. Gerakan intelektual model inilah yang ditengarai pada tiga dekade kemudian mewujudkan adanya Konsili Vatikan II. ${ }^{7}$

Daniélou, salah satu tokoh penting Nouvelle Théologie, menunjukkan adanya krisis berupa keterpisahan antara teologi dan kehidupan konkret. Daniélou merumuskan bahwa teologi bisa menanggulangi krisis tersebut dengan tiga hal. Pertama, teologi harus memperlakukan Allah sebagai Allah, bukan sebagai obyek tetapi subyek. Untuk melakukan hal ini para teolog perlu kembali kepada tiga hal yaitu Kitab Suci, para Bapa Gereja, dan Liturgi. Kedua, teologi perlu masuk dalam dialog dengan perkembangan filsafat kontemporer. Teologi perlu mengatasi persoalan putusnya relasi antara teologi dan kehidupan melalui cara berdialog dengan filsafat kontemporer terutama Marxisme dan Eksistensialisme. Ketiga, teologi harus berfungsi sebagai suatu sikap konkret atau semacam respon yang bersinggungan dengan manusia secara menyeluruh. Ini berarti bahwa teologi dan spiritualitas, juga teologi dan moral harus terintegrasi. Teologi memerlukan suatu perspektif yang universal, teologi yang berinkarnasi dalam budaya-budaya besar dunia. Meskipun pewahyuan sudah selesai dengan karya penebusan Kristus, inkarnasi iman Kristiani ke dalam budaya-budaya yang berbeda akan menunjukkan aspekaspek baru kekayaan iman akan Kristus. ${ }^{8}$

Bagi Daniélou karakter ekstrinsik adikodrati dari para neo-Thomis merupakan penyebab putusnya relasi antara teologi dan 
hidup. Ia yakin bahwa teologi wajib berhubungan dengan pengalaman-pengalaman aktual manusia dalam kehidupan seharihari, yang kodrati dan yang adikodrati harus disambung kembali. Oleh karena itu ontologi sakramental dari Nouvelle Théologie merupakan keinginan untuk menyambungkan kembali antara yang kodrati dan yang adikodrati. ${ }^{9}$

Para teolog Nouvelle Théologie yakin bahwa Allah telah menciptakan manusia dengan akhir adikodrati, oleh karenanya yang adikodrati bukanlah intervensi ilahi yang ekstrinsik pada yang kodrati. Pemisahan yang tegas justru menjadikan yang kodrati itu menjadi melulu otonom atau sekular. Teologi para neo-Thomis justru mengesahkan penerimaan modernitas atas otonomi kodrat dan juga kepercayaan Pencerahan akan kemajuan umat manusia di dalam ranah yang kodrati. Hal ini justru merupakan sebuah ironi karena para neoThomis menolak Pencerahan dan sekularisme yang dibawanya. Hanya dengan menyambungkan kembali yang kodrati dengan yang adikodrati, tersambunglah teologi dengan hidup. Hanya dengan cara ini iman dan teologi menjadi bermakna bagi masyarakat kontemporer.

\section{DASAR FILOSOFIS PEMIKIRAN DE LUBAC}

Dalam bidang filsafat, de Lubac banyak membaca karya-karya Maurice Blondel. Pemikiran Blondel yang paling berpengaruh adalah pemikiran mengenai metode imanensi atau juga yang dikenal sebagai filsafat tindakan yang berkembang pada akhir abad XIX. Berpangkal dari pokok pemikiran mengenai "tindakan", Blondel meyakini bahwa problem filosofis untuk memahami makna dan destinasi tindakan manusia tidak akan pernah terelakkan. Metode yang dipakai Blondel di dalam L'Action untuk menjawab problematika filosofis tersebut adalah metode imanensi. ${ }^{10}$ Pemikiran mengenai metode imanensi ini terus menunjukkan pengaruhnya pada perkembangan teologi Katolik abad XX. Sumbangan penting metode imanensi ini adalah adanya pemahaman yang lebih penuh tentang dialektika transendensi dan imanensi di dalam diri manusia.
Blondel di dalam L'Action ingin menunjukkan dialektika yang ada dalam tindakan manusia. Ia mau membuktikan bahwa lewat jalan tersebut manusia sampai pada sesuatu yang melebihi tindakan itu sendiri, yaitu sampai kepada transendensi. Ia memakai istilah volonté voulante atau yang dalam bahasa Inggris disebut sebagai willing will dan volonté voulue atau willed will. Dengan kedua macam bentuk kehendak ini, Blondel menunjuk pada inti dialektika tindakan manusia yaitu kesenjangan antara kehendak dan pemenuhannya. Dengan istilah tersebut Blondel membedakan antara kehendak yang menghendaki terus dan kehendak yang puas ketika mencapai apa yang dikehendaki. Dengan demikian Blondel menunjukkan perbedaan antara kehendak yang tak terpuaskan yang mengarah pada apa yang dapat memenuhi keinginan manusia secara total dan kehendak yang sifatnya empiris, yang mengarah pada obyek-obyek konkret. ${ }^{11}$

Tindakan manusia tidak mungkin mencapai kepenuhannya sehingga tindakan itu sendiri tidak mungkin menjadi tujuan terakhir manusia. Imanensi perbuatan menunjuk pada transendensi dan hanya transendensi ilahi yang dapat menuntaskan tindakan dan menjadi tujuan akhir manusia. Dengan dasar pemikiran ini Blondel menunjukkan secara filosofis bahwa dinamisme tindakan manusia menyasar pada tujuan yang sifatnya tidak lagi kodrati. Dengan demikian bisa diringkas bahwa bagi Blondel, perbedaan kontras antara yang imanen dan yang transenden mencapai sintesisnya di dalam tindakan, yang tidak lain merupakan realisasi diri Ada di mana yang imanen itu menyatakan dirinya sebagai yang transenden. ${ }^{12}$

De Lubac menyebut Blondel sebagai filsuf yang memberi rangsangan bagi para teolog untuk kembali pada tradisi yang lebih otentik. Memang pemikiran Blondel pertama-tama bukan suatu pemikiran teologi, namun pemikirannya telah menggoncang teori dualistik yang menurut de Lubac telah merusak pemikir-an Kristiani. Pemikiran Blondel telah menunjukkan sisi lemah pemikiran ekstrinsikisme. ${ }^{13}$ Dengan filsafatnya Blondel melampaui oposisi antara ekstrinsikisme 
dan imanentisme. Bagi de Lubac ekstrinsikisme telah merusak pemikiran Kristiani dan imanentisme telah menghancurkan unsur misteri.

\section{ONTOLOGI SAKRAMENTAL}

Filsafat Blondel membuka jalan pada pemahaman baru mengenai hubungan antara yang imanen dan transenden. Filsafat Blondel mempengaruhi ontologi sakramental de Lubac dan para teolog Nouvelle Théologie. Ontologi sakramental dari Nouvelle Théologie memperhatikan hubungan antara tanda sakramental (signum) dan realitas (res) dari suatu misteri yang menyangkut hubungan antara yang kodrati dan yang adikodrati, makna historis dan makna spiritual Kitab Suci, sejarah yang sekular dan yang suci, perkembangan kebenaran ajaran dalam bahasa manusia, dan ciri ekaristis dari Gereja. Terhubungnya signum dan res berarti bahwa penampakan yang eksternal serta temporal sudah berisikan yang spiritual yaitu realitas kekal yang dihadirkan dan yang kepadanya ditunjuk. Singkat kata, bagi para teolog Nouvelle Théologie kodrat secara inheren sudah mengarah kepada yang adikodrati.

Unsur paradoks sangat jelas nampak dalam ontologi sakramental de Lubac dan juga para teolog Nouvelle Théologie yang mengalir dari filsafat Blondel. Ontologi ini memberi perhatian pada realitas yang nampak dan tersembunyi sekaligus. Unsur kodrati dan adikodrati mendapat tempat yang sama. Yang kodrati dan adikodrati tersambung kembali setelah sebelumnya di dalam teologi keduanya terpisahkan secara ketat dan justru menjadi rangsangan jauh bagi adanya sekularisme. Ontologi sakramental de Lubac mengritik paham vertikalisme yang keliru karena justru memberi ruang bagi adanya horisontalisme yang meyakini bahwa dunia mempunyai makna pada dirinya sendiri terlepas dari Yang Transenden.

Ontologi sakramental de Lubac meyakini adanya hubungan yang tak terpisahkan antara signum dan res. Hal ini tercermin pula dalam pandangannya mengenai Gereja yang dipahami sebagai ikatan dua dunia. Di satu sisi Gereja merupakan tanda yang pada dirinya sendiri tidak bermakna tetapi di sisi lain mutlak perlu. Pemahaman ini perlu untuk melihat relasi antara Gereja dan dunia. Gereja memang berkecimpung di dalam dunia tetapi ia tidak melupakan panggilan eskatologisnya. Dari pandangan ontologi sakramental semacam ini de Lubac membangun pandangan eklesiologi komunionya. Eklesiologi komunio menghindari paham Gereja yang hanya didasarkan pada kesatuan statistik dan geografis. Dalam paham komunio, Gereja dilihat dalam lima dimensi relasionalnya yaitu Ilahi, mistik, sakramental, historis, dan sosial.

Pandangan mengenai Gereja sebagai sakramen mempunyai konsekuensi praktis yaitu keberanian untuk sekaligus menerima unsur keilahian dan kemanusiaan Gereja. Dalam kata sakramen tergambar relasi antara yang nampak dan yang tersembunyi, antara tanda sakramental (signum) dan realitas (res). Dengan kata lain, hubungan antara signum dan res mau menunjukkan bahwa di dalam yang nampak dan bersifat temporal sudah terkandung yang spiritual atau kekal.

\section{PANDANGAN EKLESIOLOGI DE LUBAC}

Ontologi sakramental yang dipahami de Lubac sangat mempengaruhi pandangan eklesiologisnya. Hal ini tercermin dari apa yang ia tuliskan di dalam buku Catholicism. Dalam Catholicism de Lubac mempunyai sejumlah kesimpulan mengenai struktur dan identitas Gereja. Pertama, di dalam misteri inkarnasi, Sabda Allah bukan hanya menjadi tubuh manusiawi dalam arti bahwa inkarnasi tidaklah semata-mata corporatio namun juga suatu concorporatio atau menjadi daging bersama yang lain. Kedua, Gereja bukan pertama-tama suatu institusi bersifat yuridis atau hirarkis tetapi suatu misteri. Gereja adalah suatu convocatio sebelum menjadi congregatio. Ketiga, Gereja adalah suatu realitas yang radikal inklusif. Gereja adalah congregatio generis humani, suatu kumpulan yang dihasilkan dari penyatuan semua manusia: Ecclesia ex circumcisione, ecclesia ex gentibus. Manusia tidak diciptakan untuk Gereja, namun Gereja diciptakan untuk manusia. Keempat, Gereja adalah komunitas yang di dalamnya 
manusia menemukan kembali kesatuannya yang hilang. Rahmat pemulihan (reparatio) terjadi di dalam Gereja. ${ }^{14}$

Ada banyak kesamaan pandangan eklesiologis de Lubac dengan apa yang nantinya muncul dalam Konsili Vatikan II. Von Balthasar di dalam buku The Theology of Henri de Lubac memberikan ringkasan singkat isi buku de Lubac tentang Gereja yang berjudul Méditation sur l'Église atau yang kemudian diterjemahkan ke dalam bahasa Inggris dengan judul The Splendour of the Church. Dalam ringkasan itu Balthasar memberikan komentar bahwa keseluruhan karya de Lubac ini memang terjadi pada masa sebelum konsili, tetapi ide-ide di dalam buku ini sangat berdampak pada teologi (khususnya eklesiologi) Konsili Vatikan II. Dalam karya de Lubac ini sudah muncul gagasan mengenai Gereja sebagai misteri (bab I); Gereja sebagai yang sekaligus convocatio (dari atas, dari Allah) dan congregatio (dari manusia, dari bawah), Gereja adalah sekaligus yang kelihatan dan yang tidak kelihatan (bab III), Gereja di tengah-tengah dunia (bab V), dan juga Gereja sebagai sakramen Kristus (Bab VI). ${ }^{15}$

Pandangan de Lubac mengenai Gereja sebagai misteri atau sakramen dirumuskan dengan sangat jelas di dalam Splendour of the Church. Ia menulis demikian:

\begin{abstract}
"Gereja bersifat sakramental, ia adalah ikatan antara dua dunia dan Gereja yang mempunyai ciri ganda. Di satu sisi, ia adalah tanda dari sesuatu yang lain. Tanda-tanda bukanlah hal-hal yang berhenti pada dirinya sendiri karena mereka pada dirinya tidak bermakna. Dari pengertian tanda ini bisa dipahami bahwa tanda adalah sesuatu yang nampak dan dengan jelas menunjuk pada apa yang ditandakannya. Seperti kata-kata yang tidak bermakna apapun jika tanpa acuan pada gagasan tertentu yang ditunjuk. Tanda menyatukan dua istilah yang memang dimaksudkan untuk dihubungkan. Tanda tidak membuat jarak antar keduanya, tetapi menyatukan mereka dengan menjadikan hadir apa yang dimohon." 16
\end{abstract}

Dalam hal eklesiologi, de Lubac menyumbangkan gagasan besar mengenai paham Gereja sebagai komunio. Paham ini sangat dipengaruhi oleh ontologi sakramental yang didasarkan pada filsafat Blondel. Dalam gagasan eklesiologi komunionya, de Lubac berfokus pada dimensi relasional untuk membantu memahami Gereja secara utuh. Menurut Doyle ada lima dimensi relasional pokok yang sering diacu oleh para teolog untuk memahami Gereja. Kelima dimensi itu adalah: ilahi, mistis, sakramental, historis, dan sosial. ${ }^{17}$

Pertama, dimensi relasional yang bersifat ilahi. Perlu diingat bahwa Gereja pertama-tama adalah undangan untuk berbagi dalam kehidupan ilahi. Allah tidak menjadikan manusia untuk tetap berada dalam batas-batas kodratnya. Allah juga tidak menjadikan manusia demi memenuhi tujuannya sendiri. Allah menjadikan manusia supaya manusia diangkat ke dalam persekutuan dengan kehidupan Trinitas.

Kedua, dimensi relasional yang bersifat mistik. De Lubac memahami dimensi mistik di mana gambaran-gambaran dan simbol-simbol dipakai untuk mengekspresikan pemahaman Gereja sebagai misteri. De Lubac mengajarkan bahwa Kitab Suci tidak semata-mata bersifat literer. Di sana termuat simbolisme mistik dari apa yang diwahyukan. Pembacaan yang lebih kaya atas Kitab Suci membantu untuk melihat relasi antara Allah dan manusia dan juga sejarah keselamatan umat manusia. Gereja adalah sungguh Tubuh Mistik Kristus dan di dalamnya hadir kesatuan spiritual dan sosial, kesatuan seluruh umat manusia.

Ketiga, dimensi relasional yang bersifat sakramental. Perkembangan pemahaman mengenai Gereja sebagai sakramen sudah ada dalam buku de Lubac Catholicism. Ia menulis demikian: "Jika Kristus adalah sakramen Allah, Gereja adalah bagi kita sakramen Kristus bagi manusia; Gereja menghadirkan Dia secara penuh, ia sungguh membuat Kristus hadir." 18

Bagi de Lubac, bentuk sakramental dari relasi antara yang kelihatan dan tidak kelihatan adalah sesuatu yang mengikat Gereja sebagai Tubuh Mistik Kristus dengan Gereja sebagai Umat Allah yang sifatnya historis. Bagi de Lubac, sakramentalitas Gereja tidak hanya menghubungkan yang 
nampak dan yang tidak nampak, tetapi juga yang lokal dan yang universal. Gereja merupakan keseluruhan di dalam setiap bagian-bagiannya.

Keempat, dimensi relasional yang bersifat historis. Di dalam Catholicism de Lubac sudah menekankan bahwa Gereja adalah sekaligus Tubuh Mistik Kristus dan di saat yang sama juga umat Allah. De Lubac menunjuk dimensi hisotris Gereja setidaknya dalam tiga cara. Pertama, ia menekankan hubungan antara Kristianitas dan Yudaisme. Gereja mempunyai kesatuan sejarah yang mendaging dan menemukan akarnya dalam Yudaisme dan berlanjut dalam Gereja sebagai suatu umat Allah dalam peziarahan. Menurut de Lubac, penggunaan gambaran umat Allah di dalam Lumen Gentium adalah untuk menangkap dimensi historis Gereja dalam perjalanannya sepanjang sejarah. Kedua, de Lubac mengakui bahwa Gereja di dalam sejarah tidak selalu menepati janji-janjinya. Sebagaimana yang sudah disebutkan sebelumnya, de Lubac mengacu pada paradoks bahwa Gereja yang adalah mempelai Anak Domba itu adalah sekaligus juga seperti "pelacur" yang memerlukan penebusan. Ia menyatakan bahwa pada level individu, di antara para anggota Gereja dan juga para pemimpinnya, ada kelemahan manusiawi yang mendukung perkembangan dari yang jahat. Ada pula saat di mana Gereja bereaksi secara sempit dan menghianati kekatolikannya sendiri. Ketiga, de Lubac menekankan bahwa keselamatan adalah sesuatu yang harus diperjuangkan secara riil di dalam sejarah. Jika keselamatan yang ditawarkan Allah pada dasarnya adalah keselamatan umat manusiadan umat manusia itu hidup dan berkembang di dalam waktu, maka setiap hal dari keselamatan ini secara kodratiah mengambil wujud historisnya.

De Lubac dengan sangat jelas menunjukkan adanya kontras antara ketidaksempurnaan mereka yang membentuk Gereja dan kebesaran misi ilahi yang diemban Gereja. Ia menulis di dalam Splendour of the Church demikian:

$\begin{array}{lrr}\text { "Memang ada } & \text { kontras } & \text { antara } \\ \text { ketidaksempurnaan } & \text { mereka } & \text { yang }\end{array}$

membentuk Gereja dan kebesaran misi ilahi Gereja. Meskipun demikian hal tersebut tidak menjadi masalah. Kesadaran akan hal tersebut justru menjadi rangsangan. Kesadaran akan kontras ini justru menyatakan bahwa kritisisme yang diarahkan keluar malah akan menjadi sesuatu yang tidak lebih dari pada pencarian alibi. Alibi ini menjadikan orang-orang Gereja mengelak untuk memeriksa batinnya sendiri. Pemeriksaan batin Gereja justru menjadi penting karena hal tersebut akan melawan ilusi-ilusi yang ada. Hal ini akan membantu setiap orang untuk kembali mencintai Gereja." 19

Kelima, dimensi relasional yang bersifat sosial. De Lubac melihat dimensi historis Gereja erat terkait dengan dimensi sosial Gereja. Dalam Catholicism, de Lubac membukanya dengan mengritisi pemahaman Kristianitas yang bersifat individualistik. Gereja perlu dipahami sebagai paguyuban umat yang percaya. Dengan menyatakan hal ini tidak berarti bahwa yang individual menjadi tidak penting. De Lubac mengingatkan bahwa penekanan pada dimensi sosial tidak berarti meminimalkan kepribadian individual atau mistisisme kehidupan interior individual. Bagi de Lubac, elemen yang khas dari Kristianitas terletak pada kemampuannya untuk menyatakan secara bersamaan tujuan transenden dari setiap individu dan tujuan transenden dari seluruh umat manusia. Sakramen mempunyai dimensi sosial karena sebagai sarana-sarana keselamatan, mereka adalah instrumen-instrumen kesatuan. ${ }^{20}$

\section{ANCAMAN-ANCAMAN TERHADAP GEREJA}

Pandangan eklesiologis de Lubac memberi gambaran mengenai bagaimana seharusnya Gereja memahami dan menempatkan diri. Kegagalan dalam memahami identitas Gereja menjadikan Gereja terseret ke dalam bahaya keduniawian. Bagian ini akan memperlihatkan secara lebih jelas apa saja yang menjadi ancaman bagi Gereja. Dengan kata lain, bagian ini akan menunjukkan bagaimana dan dengan cara apa saja, keduniawian itu bisa merusak Gereja. 
Keduniawian merupakan ancaman besar bagi Gereja. Ia bekerja dengan penuh tipu daya. De Lubac menyebut bahwa keduniawian yang dirohanikan merupakan ancaman paling serius di dalam Gereja. De Lubac banyak menunjukkan "cara kerja" keduniawian ini di dalam bukunya The Splendour of the Church. Berikut ini akan disampaikan sejumlah gagasan yang menjadi ancaman Gereja sebagaimana yang ditangkap penulis dari pembacaan atas The Splendour of the Church. Poin-poin berikut ini tidak terpisah satu dengan yang lain dan bahkan malah terkesan tumpang tindih.

Pertama, de Lubac melihat dan mengingatkan bahwa Gereja di tengah dunia adalah Gereja di tengah konflik. Gereja di dunia adalah Gereja yang berjuang. Allah yang ia imani adalah Allah damai dan dirinya adalah pembawa damai. Gereja menghendaki anggotanya supaya menjadi orang yang lembut dan cinta damai. Gereja menyerukan Dia yang membawa damai lewat darah-Nya di kayu salib dan ketika pesan-Nya disampaikan maka ia selalu mendamaikan. Meskipun demikian proses itu harus dimulai dengan mengoyak manusia dari rasa nyaman dan damai yang semu. Setiap upaya kepada pembebasan, upaya membebaskan manusia dari perbudakannya selalu menimbulkan adanya konflik. Maka sebelum Gereja bisa menjadi Yerusalem yang bersuka cita, yang merayakan Tuhannya di dalam kedamaian yang akhirnya tergapai, ia harus berjuang dan bekerja keras seperti layaknya Yakub. Sebelum ia dimahkotai di tempat yang tinggi ia harus berperang dengan kekuatan dunia ini. Dalam perjuangan itu Gereja tidak akan pernah mengalami kemuliaan dan menikmati kekuasaan di dalam dunia ini meskipun ilusi semacam ini berulangkali muncul dalam diri anggota Gereja. ${ }^{21}$

Kedua, seseorang yang percaya bahwa dirinya adalah seorang nabi, atau kaya dalam rahmat rohani, harus memperingatkan dirinya sendiri bahwa di atas semuanya itu ia terikat untuk menyerahkan diri pada perintah-perintah Tuhannya sebagaimana yang diajarkan Gereja. Jika tidak demikian maka akan sia-sialah nubuat yang ia berikan. Semua anugerah yang ia punyai hanya akan menuntun dia kepada kehancurannya sendiri. Siapa saja yang memberi jalan kepada godaan-godaan spiritualisasi yang keliru dan ingin melepaskan diri dari Gereja sebagai kuk yang membebani atau mengesampingkan Gereja sebagai pengantara yang membebani akan mengalami kehampaan atau akan berakhir dengan menyembah allah-allah yang keliru. Jika seseorang mulai menggunakan Gereja sebagai dukungan baginya dan oleh karenanya menjadi percaya bahwa ia bisa melampauinya, ia akan menjadi tidak lebih dari seorang mistik yang keluar dari rel. Mereka yang mengharapkan suatu masa depan, Yerusalem Surgawi, yang akan membuka periode baru sejarah di bumi dan akhirnya menjamin kejayaan spiritual yang penuh boleh membayangkan bahwa mereka menubuatkan bahwa umat manusia kembali kepada surga yang telah hilang. Namun di dalam realitanya hal tersebut tidak lebih dari pada suatu impian yang sakit dan dikuasai keangkuhan. Oleh karenanya Tertulianus pernah mengatakan: "Kekerasan hati meraja sampai dengan Kristus, dan kelemahan daging bertahan sampai datangnya Penghibur." Penyeruan "Abad Ketiga", suatu abad kontemplatif yang menggantikan abad para "Doktor Gereja", atau Gereja Yohanes yang mengikuti Gereja Petrus, atau Kerajaan Roh masa depan yang mengikuti Kerajaan Kristus dan para murid Gereja-Nya, semuanya ini telah menimbulkan skisma-skisma yang merusak. ${ }^{22}$

Ketiga, Gereja tidak bisa diukur dari kejayaan manusiawinya. Gereja, keseluruhan Gereja, satu-satunya Gereja, Gereja sekarang, kemarin, dan yang akan datang adalah sakramen Kristus. Meskipun demikian, ada banyak pihak yang ingin menjadi musuh Gereja. Mereka memahami secara keliru kodrat Gereja dan hanya melihatnya dari kejayaan manusiawinya. Mereka ini tidak menyadari bahwa dirinya sendiri perlu untuk mengubah pandangan mereka seturut dengan ajaran Gereja. Mereka menunjukkan kepada Gereja "segala rasa hormat" dan bahkan kerap kali terlalu jauh merasakan semacam afeksi filial. Beberapa dari mereka tersentuh dengan kuasa memerintah dan melestarikan apa yang menjadi tujuan Gereja. Mereka mengagumi 
ketahanan Gereja yang sudah teruji sejak lama terutama stabilitasnya yang mengagumkan di tengah-tengah badai zaman dan lain sebagainya. Bagi mereka, Gereja lebih dari pihak yang memaklumkan dan menjaga Injil atau pewaris budaya Yunani dan Romawi. Bagi sebagian yang lain ia hanyalah anti ini dan itu. Sementara yang lain melihat bahwa di dalam Gereja ada dinamisme yang besar yang memberikan daya bagi kebekuan mereka, memenuhi hati dari sedikit orang yang terpilih dengan hasrat akan keadilan. Para humanis mungkin memuji Gereja karena selama Abad Gelap telah berhasil menjaga kebudayaan kuno di biara-biara. Mereka bersyukur karena dukungan Gereja kepada seni juga atas apresiasinya kepada keindahan liturgi. Ada sejumlah orang yang sangat pintar, yang sangat sadar akan berbagai persoalan dunia masa kini, yang merasa sangat percaya kepada Gereja sebagai satusatunya kekuatan spiritual yang mampu menguasai persoalan-persoalan tersebut dan memecahkannya. Pujian bebas diberikan kepada banyak peran Gereja dalam mempengaruhi kebudayaan, disiplin moral, karya pendidikan, dan kasihnya serta perhatian yang ia tunjukkan kepada setiap fase kehidupan manusia. ${ }^{23}$

De Lubac menulis pernyataan tegas bahwa Gereja tidak ada demi pencapaian atau keuntungan yang sifatnya manusiawi:

\begin{abstract}
"Kita sama sekali tidak memahami Gereja jika kita hanya melihatnya dalam kacamata keuntungan manusiawi belaka; atau jika kita melihat Gereja melulu sebagai sarana demi suatu tujuan yang sifatnya temporal betapapun terhormatnya hal tersebut; atau jika kita sebagai umat beriman di dalam Gereja tidak pertama-tama menemukan misteri iman. Dalam situasi semacam ini, segala yang dikagumi dari Gereja, dan segala pujian terhadap Gereja adalah kesiasiaan." ${ }^{24}$
\end{abstract}

Ada bahaya untuk menempatkan Gereja tidak dalam unsur sakramental atau misterinya. Jika orang berbicara mengenai Gereja dan hanya soal Gereja saja, maka sebenarnya orang tidak menunjukkan Gereja dalam realitas-realitas sakramentalnya. Meskipun tanpa bermaksud demikian, orang membiarkan penglihatannya mengenai Gereja terhenti pada Gereja tanpa unsur misterinya. Jika Gereja kehilangan unsur misteri maka ia menjadikan Injil dari dirinya sendiri. Hal ini sama seperti yang diungkapkan oleh Karl Barth: "Jika Gereja tidak mempunyai tujuan lain dari pada pelayanan kepada dirinya sendiri, ia membawa bagi dirinya sendiri stigmata kematian." ${ }^{25}$

Keempat, setiap anggota Gereja perlu menjadi rendah hati dan menyadari bahwa mereka tidak mewartakan dirinya sendiri. Gereja tidak bisa disamakan dengan apa yang mereka pikirkan sendiri. Setiap umat beriman adalah anggota tubuh yang unik, yang ada di jalannya sendiri-sendiri. Setiap dari umat beriman adalah Gereja. Gereja dimaksudkan untuk mewartakan Injil melalui setiap anggotanya kepada setiap ciptaan. Ia dimaksudkan untuk menjadi cahaya yang menyinari mata setiap orang yang datang ke dunia ini. Di dalam setiap diri umat, Gereja dimaksudkan untuk mengosongkan dirinya sendiri di hadapan Tuhan. Ia menjadi tidak lebih dari pada jari yang menunjuk ke arah Dia. Setiap anggota Gereja di jalannya sendiri-sendiri dimaksudkan untuk menjadi pelayan Sabda. Injil tidak hanya diwartakan melalui kata-kata saja. Injil dinyatakan terlebih-lebih dengan hidup. Dengan hidup oleh Roh Kristus, Gereja menyatakan Dia dan mewartakan nama-Nya. ${ }^{26}$

Seringkali ada orang yang selalu mengidentifikasikan Gereja dengan apa yang mereka pikirkan sendiri. Seringkali pengidentifikasian ini dilakukan dengan "bungkus-bungkus" kesalehan dan nampak baik. Meskipun demikian orang tidak memahami bahwa jika mereka adalah pelayan yang setia kepada Gereja, maka mereka harus mau banyak bermatiraga. Mereka perlu memahami bahwa di balik hasrat mereka melayani Gereja, mereka justru memaksa Gereja menuruti kemauan mereka sendiri. ${ }^{27}$

Kelima, ada bahaya bahwa karya-karya Gereja hanya mengarah kepada hal-hal yang sifatnya temporal. Gereja bisa saja menemukan di dalam dirinya hal-hal yang sifatnya satanik dalam arti semuanya 
diarahkan untuk dirinya sendiri. Meskipun demikian, dari sejarahnya Gereja bukanlah budak zaman atau dari apapun yang sifatnya temporal. Pesan yang mengikat dan wajib Gereja wartakan tidak pernah menjadi bagian integral dari entah itu rezim politik, pemerintahan, atau suatu bentuk peradaban partikular tertentu. De Lubac mengutip kata-kata Augustinus untuk menunjukkan hal ini: "Mengapa kamu cemas ketika kerajaan duniawi berlalu?" De Lubac mau mengatakan bahwa Gereja tidak pernah terserap sepenuhnya atau menjadi bagian dari hal-hal yang sifatnya temporal. Gereja didirikan bukan di atas batu selain iman Petrus, yang tidak lain adalah iman kepada Yesus kristus. Gereja bukanlah sebuah partai atau sebuah masyarakat tertutup. Anggota Gereja perlu belajar untuk setia kepada keyakinan ini. Siapapun yang ada di dalamnya harus berjaga-jaga supaya tidak hanyut menjadi "manusia kedagingan", yang sebenarnya sudah ada sejak generasi pertama umat Kristiani. Kecenderungan ini menjadikan Gereja menjadi semacam properti privat mereka sendiri, yang secara praktis menghalangi para rasul untuk mewartakan Injil kepada bangsa-bangsa lain di luar bangsa Yahudi. ${ }^{28}$

De Lubac menyatakan bahwa setiap anggota Gereja perlu menyadari bahwa pengetahuan manusia itu sifatnya selalu parsial. De Lubac mengutip pemikiran Newman bahwa alih-alih menjadikan Gereja menjadi properti privat dan kurang lebih mengidentifikasikan Gereja dengan diri kita sendiri, kita seharusnya lebih memberi perhatian untuk mengidentifikasikan diri kita dengan Gereja tanpa mengharapkan hasil apapun darinya. ${ }^{29}$

Keenam, ketika badai menerjang Gereja ada bahaya bahwa banyak anggotanya merasa seolah-olah berdiri di luar Gereja. Ada bahaya pula untuk memandang Gereja yang di dunia ini sebagai realita yang tanpa cela. Ketika eksistensi Gereja dipertanyakan atau dikritik, umat beriman seharusnya tidak menghakimi terlebih dulu atau malah mundur. Kebaikan adikodrati yang dilayani Gereja di dunia ini adalah sesuatu yang menjangkau kepenuhannya di dalam tatanan yang tidak nampak, di dalam kekekalan. Komunio para kudus bertumbuh dari generasi ke generasi dan seharusnya Gereja tidak mundur dan terjebak pada impian yang menampakkan sisi kejayaan luaran. Gereja harus kembali mengingat bahwa Kristus Sang Kepala Gereja tidak menjanjikan kejayaan atau kesuksesan. ${ }^{30}$

Ketujuh, tidak ada yang disebut sebagai Kristianitas privat. Jika mau menerima Gereja, maka ia harus diterima sebagaimana adanya dia, di dalam realitas manusiawinya hari demi hari. Gereja harus diterima apa adanya sama seperti juga saat umat mencintai keilahian yang menjadi unsur Gereja. Realitas kemanusiawian dan keilahian Gereja tidak bisa dipisahkan. Pemisahan antara keduanya tidaklah mungkin. Mencintai Gereja berarti mencintainya secara penuh. Misteri penyelamatan tidak bisa menjangkau manusia tanpa mediasi. Logika yang dipakai adalah logika inkarnasi, yaitu ketika keilahian menyesuaikan diri dalam kelemahan manusia. Hal sama juga berlaku seperti apa yang pernah diutarakan St. Paulus yaitu bahwa harta yang berharga tersimpan di dalam bejana tanah liat. ${ }^{31}$

Kedelapan, ada bahaya narsisme di dalam Gereja. Orang yang merasa lebih superior akan memandang rendah Gereja. Mereka menemukan kepuasan dalam pikiran-pikiran mereka sendiri. Orangorang semacam ini mengagumi pemikirannya sendiri dan seringkali tidak sadar bahwa sedang ada dalam suatu kesia-siaan. Pengakuan secara intelek mengenai kekatolikan tidak secara otomatis juga menganugerahkan kesucian. Ada banyak kesempitan di dalam diri manusia yang sering menjadi penghalang Roh untuk berkarya. De Lubac menyatakan bahwa seorang kudus yang paling rendah hati itu lebih merdeka secara batin dari pada orang-orang yang paling bijaksana.

Kesembilan, keduniawian merupakan ancaman terbesar Gereja. Gereja sebagai Ibu tidak pernah berhenti untuk melahirkan anak-anaknya kepada kehidupan Roh. Godaan terbesar bagi Gereja yang diciptakan oleh anak-anaknya sendiri, sesuatu yang paling subversif dan selalu berulang, yang selalu penuh dengan tipu daya, dan bahkan sering diperkuat oleh mereka yang 
unggul adalah "keduniawian". Ia menjadikan patokan-patokan moral dan bahkan spiritual tidak didasarkan pada kemuliaan Tuhan, tetapi pada apa yang menguntungkan manusia. Ia nampak dalam tampilan yang sepenuhnya antroposentris. Bahkan jika manusia dipenuhi dengan kesempurnaan spiritual, namun jika hal itu tidak mengacu kepada Allah, maka hal terebut akan menjadi keduniawian. Jika keduniawian masuk ke dalam Gereja dan merusaknya dengan menyerang prinsip dasarnya, maka hal itu akan lebih merusak dari pada keduniawian lainnya, termasuk keduniawian dalam tatanan moral. Ia bahkan lebih buruk dari pada kusta yang dalam titik tertentu dalam sejarah menimbulkan kerusakan pada sang mempelai. Hal tersebut terjadi saat agama nampak menciptakan skandal di tempat kudusnya sendiri yang ditampakkan oleh Paus yang dipenuhi hawa nafsu, yang menyembunyikan wajah Kristus di balik perhiasan, polesan, dan hal-hal yang indah. ${ }^{32}$ Tidak ada seorangpun kebal terhadap jenis godaan ini. Humanisme yang penuh tipu daya yang adalah musuh Allah bisa menemukan jalan masuknya ke dalam hati manusia dengan seribu satu cara.

\section{SPIRITUAL WORLDLINESS DALAM GEREJA ZAMAN INI}

Pada bagian sebelumnya dijelaskan dengan panjang lebar mengenai ancaman keduniawian terhadap Gereja masa kini sebagaimana dipahami Paus Fransiskus. Paus Fransiskus tidak henti-hentinya memperingatkan Gereja untuk berhati-hati dan senantiasa memeriksa dirinya supaya tidak terjerumus ke dalam keduniawian ini. Berikut ini akan dijabarkan mengenai pemahaman Paus Fransiskus mengenai spiritual worldliness sebagaimana yang ia ambil dari pemikiran de Lubac.

Dalam anjuran apostolis Evangelii Gaudium Paus Fransiskus dengan jelas mengangkat tema mengenai keduniawian sebagai ancaman Gereja di masa ini. Pemikiran ini ia kutip dari buku karangan Henri de Lubac berjudul the Splendour of the Church. Paus Fransiskus mengatakan bahwa keduniawian ini bisa tersamar dalam olah kesalehan dan bahkan dalam rasa cinta kepada Gereja. Di balik kesalehan dan rasa cinta itu sebenarnya yang dicari bukan kemuliaan Allah tetapi kemuliaan dan keselamatan diri sendiri. Dalam ekshortasi ini Paus Fransiskus menunjukkan bahwa spiritual worldliness mengarah pada dua kutub. Yang pertama mengarah pada gnostisisme di mana iman sepenuhnya dipahami secara subyektif. Gnostisisme menaruh perhatiannya pada pengalaman atau ide-ide tertentu yang menerangi dan memuaskan manusia tetapi membuat orang justru terperangkap dalam pikiran-pikiran dan perasaan-perasaan mereka sendiri. Yang kedua spiritual worldliness ini mengarah pada neo-pelagianisme promethean yang akhirnya hanya menaruh kepercayaan pada usaha mereka sendiri dan oleh karenanya merasa superior atas orang lain. Orang merasa lebih dari pada orang lain karena sudah menjalankan berbagai macam aturan atau karena tetap setia pada gaya keKatolikan tertentu yang berasal dari masa lalu. Spiritual worldliness ini mengarah pada elitisme narsistik dan otoriter. Alihalih mewartakan Injil dan membuka pintu kepada rahmat Allah, orang menghabiskan energi untuk sibuk dan memverifikasi praktek-praktek keagamaannya. Paus Fransiskus mengatakan bahwa pewartaan yang sungguh-sungguh tidak mungkin muncul dari bentuk kristianitas semacam ini. ${ }^{33}$

Spiritual worldliness nampak dalam sejumlah praktek yang nampaknya saling berlawanan, namun semuanya mempunyai kecenderungan yang sama yaitu ingin mengambil posisi di dalam Gereja. Dalam diri beberapa pihak, spiritual worldliness nampak dalam praktek-praktek yang memberi penekanan berlebihan pada liturgi, doktrin, maupun wibawa Gereja. Orang menjadi tidak sadar bahwa praktekpraktek semacam itu sebenarnya membuat kehidupan Gereja menjadi seperti bendabenda kuno di museum. Di sisi lain, spiritual worldliness berada dan tersembunyi di balik gemerlap pencapaian sosial dan politis, dalam kebanggaan orang dalam mengelola hal-hal praktis, juga dalam obsesi terhadap program-program yang dapat mereka realisasikan. Ini semua bisa mengarahkan pada suatu mentalitas bisnis, yang membuat orang terperangkap dalam manajemen, statistik, perencanaan dan 
evaluasi, yang keuntungan utamanya sebenarnya bukan tertuju pada Gereja sebagai umat Allah tetapi Gereja sebagai sebuah institusi. ${ }^{34}$

Paus Fransiskus, menyatakan bahwa mereka yang jatuh dalam spiritual worldliness melihat segala sesuatunya dari atas dan jauh, mereka menolak kesaksian dari saudara mereka, mereka menyingkirkan orang-orang yang mengajukan pertanyaanpertanyaan kritis, dan mereka cenderung untuk terus menerus menunjuk kesalahan orang lain, mereka terobsesi dengan penampilan luaran. Hati mereka hanya terbuka pada horison yang terbatas pada imanensi dan minat mereka sendiri. Sebagai konsekuensinya, mereka tidak belajar dari dosa-dosa mereka sendiri dan oleh karenanya tidak sungguh-sungguh terbuka pada pengampunan. ${ }^{35}$

$$
\text { Uraian mengenai spiritual }
$$

worldliness dari Paus Fransiskus di atas mempunyai sejumlah pokok yang penting untuk diperhatikan. Pertama-tama Paus melihat adanya unsur kerjasama antara dimensi manusiawi dan ilahi dalam menjaga dan melestarikan Gereja. Keduanya penting tetapi yang lebih utama dari itu adalah karya Tuhan sendiri. Bukan karena karya manusia Gereja hidup dan bertumbuh sampai dengan saat ini. Hal kedua yang dilihat Paus Fransiskus adalah realitas bahwa Gereja itu adalah bait Roh Kudus, bukan rajutan kepentingankepentingan manusiawi. Kepentingankepentingan manusiawi yang tidak lain adalah keduniawian, kerap kali dispiritualkan dan tersamar dalam olah kesalehan yang dibungkus dalam rasa cinta kepada Gereja. Keduniawian ini sebenarnya mencari kemuliaan dan keselamatan diri sendiri. Paus Fransiskus menyebut kecenderungan itu dengan istilah elitisme narsistik yang otoriter, yang sibuk dengan soal benar salah praktek keagamaan. Keduniawian ini mendorong orang untuk mencari kuasa atau posisi di dalam Gereja, seolah-olah menjadi hal paling penting di dalam Gereja. Keduniawian bersembunyi entah itu di balik penekanan yang berlebihan pada soal liturgi maupun ajaran atau di balik gemerlap pencapaian sosial-politis. Keduniawian memandang Gereja sekedar dari sisi manejemen atau statistik. Ia tidak dilihat sebagai umat Allah tetapi sebagai institusi.

\section{UPAYA MELAWAN KEDUNIAWIAN: MEMPERTAHANKAN PARADOKS DAN TEGANGAN}

Keduniawian menarik misteri Gereja ke ranah kodrati. Yang kodrati dipisahkan dari yang adikodrati. Di satu sisi ada kecenderungan untuk memutlakkan yang kodrati dan menghilangkan yang adikodrati dan di sisi lain memutlakkan yang adikodrati dan menghilangkan yang kodrati. Ada unsur tegangan yang harus dijaga antara yang kodrati dan adikodrati, antara yang manusiawi dan ilahi.

De Lubac menghidupi sebuah spiritualitas tegangan. Hal ini nampak jelas dalam pemikirannya ketika tentang hubungan antara kodrat dan yang adikodrati, penolakannya terhadap ekstrinsikisme dan imanentisme, dan penekanannya pada unsur misteri serta ontologi sakramental. Spiritualitas tegangan yang mendasari teologi de Lubac bisa digunakan untuk mencermati adanya banyak tantangan yang dihadapi Gereja pada zaman ini terutama ancaman keduniawian.

Ada tegangan dinamis yang perlu dipertahankan dalam memahami identitas Gereja. Dalam menghidupi tegangantegangan ini ada unsur paradoks yang harus diterima sebagai konsekuensi. Dalam hal ini de Lubac sering disebut sebagai "ahli paradoks". Kegagalan dalam mempertahankan tegangan dan menolak paradoksparadoks di dalam Gereja menjadikan Gereja jatuh ke dalam ekstrem-ekstrem yang saling berlawanan.

Unsur-unsur "paradoks" terlihat jelas dalam buku de Lubac yang berjudul A Brief Catechesis on Nature and Grace. Relasi antara kodrat dan yang adikodrati menjadi analogi relasi antara penciptaan dan penebusan, yang imanen dan yang transenden, serta Gereja dan dunia. De Lubac memakai peristiwa inkarnasi sebagai dasar bagi paham paradoks di dalam teologinya. Inkarnasi merupakan basis bagi tegangan antara identifikasi dan distingsi dalam teologi de Lubac. Di dalam inkarnasi ada 
kesatuan hipostasis dari kodrat ilahi dan manusiawi di dalam diri Kristus. Peristiwa inkarnasi ini merupakan analogi atas paradoks terbesar Yesus Kristus sebagai Allah dan manusia. Dalam analogi ini hubungan antara dua tatanan bisa dipahami.

Keduniawian membuat Gereja menjadi kurang percaya dan bahkan melupakan bahwa Gereja ada dan berkembang hingga saat ini pertama-tama bukan karena jasa manusia tetapi karena peran Roh Kudus. Gereja tumbuh karena ia hidup di dalam tegangan antara yang manusiawi dan yang ilahi. Dalam segala yang manusiawi terpancar daya-daya Ilahi. Gereja berjuang di dalam dunia dan menjadi bagian dari dunia tetapi ia tidak berhenti di dunia. Gereja tidak bisa lari dari tanggungjawab menjadi tanda kehadiran Allah yang berkarya di dalam dunia. Di dalam dunia yang kelihatan, rahmat Allah bekerja karena dunia adalah medan inkarnasi Allah. Di dalam dunia Gereja berziarah dan berjuang menuju Yerusalem surgawi.

\section{Mario Tomi Subardjo}

Mahasiswa Pontificio Instituto Liturgico Sant' Anselmo, Roma, Italia.

Email:tomi.mariosj@gmail.com.

\section{CATATAN AKHIR}

1 http://www.news.va/en/news/bergogliosintervention -a-diagnosis-of-the-problem.

2 http://www.catholicworldreport.com/Blog/ 2136/pope

francis_and_henri_de_lubac_sj.aspx\#. UsDJ_tIW1RY.

3 http://www.catholicworldreport.com/Blog/ 2136/pope_francis_and_henri_de_lubac_sj.aspx\#. UsDJ_tIW1RY.

4 http://www.vatican.va/holy_father/francesco/ speeches/2013/june/documents/papa-francesco_ 20130621_rappresentanti-pontifici_en.html.

5 Pope Francis, Evangelii Gaudium No.93-94.

6 Joseph A. Komonchak, 1990, “Theology and Culture at Mid-Century: The Example of Henri de Lubac”, dalam Theological Studies 51, ,579-602.

7 Joseph A. Komonchak, "Returning from Exile: Catholic Theology in the 1930s", dalam dalam Gregory Baum (Ed.), 1999, The Twentieth
Century a Theological Overview, Orbis Books, New York,. 36.

8 Hans Boersma, 2009, Nouvelle Théologie and Sacramental Ontology a Return to Mystery, Oxford University Press, New York, 1-34.

9 Joseph A. Komonchak, "Returning from Exile: Catholic Theology in the 1930s, 5.

10 K.Bertens, 2006, Filsafat Barat Kontemporer , Gramedia, Jakarta, 33-34.

11 K.Bertens, 33-34.

12 Victor Consemius, "The Condemnation of Modernism and the Survival of Catholic Theology”, dalam Gregory Baum (Ed.), 1999, The Twentieth Century a Theological Overview, Orbis Books, New York, 16.

13 "Latin theology's return to a more authentic tradition has taken place-not without some jolts, of course-in the course of the last century. We must admit that the main impulse for this return came from a philosopher, Maurice Blondel. His thinking was not primarily exercised in the areas proper to the professional theologians, nor did it base itself on a renewed history of tradition. Still, he is the one who launched the decisive attack on th edualist theory which was destroying Christian thought. Time after time he demonstrated the deficiencies of the thesis of the 'extrinsicist'." Lih. Henri de Lubac, 1984, A Brief Cathechesis on Nature and Grace, Ignatius Press, San Francisco, 37.

14 Nathan D. Mitchell, 2010, “Contextualizing Henri de Lubac's Work”, dalam The Amen Corner Vol.84.

15 Hans Urs von Balthasar, 1991, The Theology of Henri de Lubac, Ignatius Press, San Francisco, 109-110.

16 "That which is sacramental-"the sensible bond between two worlds"-has a twofold characteristic. Since, in the one hand, it is the sign of something else, it must be passed through, and this not in part but wholly. Signs are not things to be stopped at, for they are, in themselves, valueless; by definition a sign is something translucent which dissolce from before the face of what it manifests-like words, which would be nothing if they did not lead straight on to ideas. Under this aspect it is meant to link. It does not put a distance between them; on the contrary, it unites them by making present that which it evokes." Henri de Lubac, 1956, The Splendour of the Church,: Sheed and Ward, London and New York, 147.

17 Dennis M.Doyle, 1999, "Henri de Lubac and the Roots of Communion Ecclesiology”, dalam Theological Studies No.60, 218.

18 "If Christ is the sacrament of God, the Church is for us the sacrament of Christ; she represents him, in the full and ancient meaning of the term, she really makes him present." Henri de Lubac, Catholicism: a study of dogma in relation to the 
corporate destiny of mankind, London: Burns and Oates, 29.

19 “....Then the staring contrast between the human wretchedness of those who make up the Church, and the greatness of her divine mission, will no longer be a scandal to us....Rather it will become a stimulus.” Henri de Lubac, The Splendourof the Church, 217-218.

20 Dennis M. Doyle, “Henri de Lubac and the Roots of Communion Ecclesiology”, 224-225.

21 We are in slavery;she is to deliver us, and deliverance does not come about without conflict. It is only as her border that God has given her peace. So, before she can be the festive Jerusalem which celebrates its Lord in a peace finally achieved, she has to pass through the status of Jacob, whose name signifies struggle and toil. Before she can be crowned on high, she must clash with the powers of this world; and she will never be in triumph and glory in it, whatever the illusions periodically recurring in some of her children. Henri de Lubac, The Splendour of the Church,135-136.

22 Henri de Lubac, The Splendour of the Church, 148-149.

23 "The Church, the whole Church, the only Church, the Church of today and yesterday and tomorrowis the sacrament of Christ; strickly speaking, she is nothing other than that....."Henri de Lubac, The Splendour of the Church.Hlm., 156-157.

24 "We no longer understand the Church at all if we see in her only her human merits, or if we see her as merely a means-however noble-to a temporal end; or if, while remaining believers in some vague sense, we do not primarily find in her a mystery of faith. Under such circumstances the very things admired in her are denatured, and her praises are mere vanity-if indeed they do not become blasphemies."Henri de Lubac, The Splendour of the Church, 158.

25 Henri de Lubac, The Splendour of the Church, 158.

26 "Each one of us is a member of the unique body, and each one of us, in his own small way, is the Church. The Church is meant to proclaim the Gospel through each one of us, and to announce it to every creature." Henri de Lubac, The Splendour of the Church, 167.

27 "There will always be men who identify their cause with that of the Church so totally that they end by equating the Church's cause with their own, and this in all good faith. It does not occur to them that if they are to be truly faithful servants they may have to mortify much in themselves; in their desire to serve the Church, they press the Church into their own service." The Splendour of the Church, 208.

28 “....We must not relax in any way our zeal for Catholic truth, but we should learn how to purify it. We must be on our guard against turning into those 'carnal men' who have existed since the first generation of Christians and who, turning the Church into their own private property, practically stopped the Apostles from announcing the Gospel to the Gentiles." Henri de Lubac, The Splendour of the Church, 210-211.

29 Lih. Henri de Lubac, The Splendour of the Church, 212.

30 "When the Church is in question we must not judge of advance and retreat, success and frustration, as we should do in the case of things which are of time.....And we should not regress into any dream of a Church exteriorly triumphant, for Church's Head did not promise her dazzling and increasing success..." Henri de Lubac, The Splendour of the Church, 222-223.

31 There is no "private Christianity", and if we are to accept the Church we must take her as she is, in human day-to-day reality just as much as in her divine and eternal ideality; for a separation of the two is impossible both in fact and by right. Loving the Church means loving her in the full massiveness of her tradition, all repugnance overcome, and burrowing deep, so to speak, into the massiveness of her life, as the seed goes deep into the earth. Henri de Lubac, The Splendour of the Church, 231.

32 " If this worldliness of the spirit were to invade the Church and set to work to corrupt her by attacking her very principle, it would be something infinitely more disastrous than any worldliness of the purely moral order-even worse than hideous leprosy which at certain moments in history inflicts so cruel a disfigurement on the Bride; when religion seems toset up the scandalous 'in the very sanctuary ifselfrepresented by a debauchee Pope, hiding the face of Christ behind jewels, rouge and beauty spots'."Henri de Lubac, The Splendour of the Church, 288.

33 Pope Francis, No.93-94.

34 Pope Francis, No.95.

35 Pope Francis, No.97.

\section{DAFTAR RUJUKAN}

\section{Buku:}

Balthasar, H, 1991. The Theology of Henri de Lubac. San Francisco: Ignatius Press.

Baum, G., 1999. The Twentieth Century a Theological Overview. Orbis Books, New York.

Bertens, K., 2006. Filsafat Barat Kontemporer Jilid II: Prancis. Penerbit PT Gramedia Pustaka Utama, Jakarta.

Boersma, H., 2009. Nouvelle Théologie and Sacramental Ontology a Return to Mystery. Oxford University Press, New York. 
Lubac, H., 1984. A Brief Catechesis On Nature and Grace. Ignatius Press, San Francisco. , 1958. Catholicism: a study of dogma in relation to the corporate destiny of mankind. Burns and Oates, London. 1956. The Splendour of the Church, Sheed and Ward, London and New York.

\section{Jurnal:}

Dennis M. Doyle, 1999, "Henri de Lubac and the Roots of Communion Ecclesiology", Theological Studies, No.60.

Joseph A. Komonchak, 1990, "Theology and Culture at Mid-Century: The Example of Henri de Lubac", Theological Studies, No.51.

Nathan D. Mitchell, 2010, "Contextualizing Henri de Lubac's Work”, The Amen Corner, Vol.84.

\section{Internet:}

Pope Francis, 2013, Evangelii Gaudium, http://w2.vatican.va/content/francesco/en/ apost_exhortations/documents/papa-

francesco_esortazione-

ap_20131124_evangelii-gaudium.html. http://gsearch.vatican.va/search?q=de+lubac\&bt $\mathrm{nG}=$ Search + on\&site=default_collection\& client=default_frontend\&output $=x m l \_n o \_$ dtd\&proxystylesheet=default_frontend $\& \mathrm{~s}$ ort $=$ date $\% 3 \mathrm{AD} \% 3 \mathrm{AL} \% 3 \mathrm{Ad} 1 \&$ entsp=a policy_documenti\&oe=UTF-8\&ie=UTF$8 \& u d=1 \&$ exclude_apps $=1 \&$ filter $=0$

http://www.news.va/en/news/bergogliosintervention-a-diagnosis-of-the-problem.

http://www.catholicworldreport.com/Blog/2136/ pope_francis_and_henri_de_lubac_sj.aspx \#.UsDJ_tIW1RY.

http://www.catholicworldreport.com/Blog/2136/ pope_francis_and_henri_de_lubac_sj.aspx \#.UsDJ_tIW1RY.

http://www.vatican.va/holy_father/francesco/spe eches/2013/june/documents/papafrancesco_20130621_rappresentantipontifici_en.html. 